\title{
Conservation Cropping Systems in Pakistani Agriculture: Incursion of Soil Surface Plant Residue on Weed Management
}

\author{
Muhammad Asad ${ }^{1,2 *}$, Zahid Mahmood ${ }^{2}$ and Muhammad Mudassar ${ }^{3}$ \\ ${ }^{1}$ Department of Agronomy, PMAS Arid Agriculture University Rawalpindi, Pakistan \\ ${ }^{2}$ Wheat Wide Crosses Program, National Agricultural Research Centre, Pakistan \\ ${ }^{3}$ Department of Environmental Economics, Pakistan Institute of Developmental Economics, Pakistan
}

Submission: September 19, 2017; Published: October 12, 2017

"Corresponding author: Muhammad Asad, Department of Agronomy, PAS Arid Agriculture University, Weed Sciences lab, Rawalpindi-46000Pakistan,Email: muhammadasad753@gmail.com

Keywords: Conservation cropping systems; Plant residue; Weed management; Soil surface

\section{Introduction}

Pakistan's agriculture community comprises small farmers having several precincts in their farming practices, due to which per yield level has been arranged in the lower to middle ranged. During 2016, the performance of agriculture sector as a whole remained drab as it perceived a negative growth of $0.19 \%$ as compared to last year which was $2.53 \%$.Major crops having a share of $23.55 \%$ in agriculture has perceived negative growth of $7.18 \%$ due to large decline in the production of cotton $(27.83 \%)$, rice $(2.74 \%)$ and maize $(0.35 \%)$ during 2015 -16 against negative growth of $0.52 \%$ during 2014-15. But only sugarcane and wheat production perceived a positive growth of $4.22 \%$ and $1.58 \%$ respectively, as compared to last year.

Soil degradation (alkalinity, soil salinity, soil fertility depletion and erosion), decrease in water availability, tyranny of irrigation systems and poor farming practices are main constraints to sustainable agriculture and producing less production in Pakistan [1]. In Pakistani soils Organic matter content for different crops is very low because of which overall fertility prestige is not adequate to bounce better yield [2]. As the $\mathrm{C} / \mathrm{N}$ rate of the plant residue got low, its decomposition become fast. Nitrate (An inorganic ion commonly present in the soil solution) affects germination of various weed species [3], and normally it is present in higher concentrations in the top soil layer, because of organic matter decomposition and microbial activity [4].
So, the addition of plant residue to the surface of soil may change the $\mathrm{C} / \mathrm{N}$ ratio in the upper layer of soil, which may stimulate the weed in the seed bank indirectly to germinate. Allelopathic effects of plant residue on the soil surface also damage the plant growth [5,6]. Allelopathic compounds released by Plant residues may suppress the growth of weed [7]. As allelopathic effects from plant residue covering the soil surface, physical effects have been suggested as the main reason of these effects on weed growth. So, the inhibitory effect was not associated to allelopathic interactions [8].

Plant residue present on the surface of soil constrains with soil micro-fauna as it increase the possibility of occurrence of insects, pests, microorganisms and other types of living organisms [9]. Numerous insects that take benefit of the existence of plant residue on the surface of soil have bad effects on weeds, acting as predators or carrying fungi that live on different plant parts of weeds [10]. Microorganisms play significant role in loss of feasibility of several weeds propagules and deterioration of weed seed existent in the soil [11]. Greater numbers of microorganisms are present in no tillage systems, due to the presence of plant residue on soil surface produces microenvironment conditions for in ordinate assortment of micro-fauna on the upper soil layer [12].

The plant residue present on the soil surface intrudes solar radiation and reduces the hydric and thermal soil fluidity, and 
also play role as a physical hurdle to regular plant growth [11]. According to these physical effects cannot be abandoned because most species of weed have dormancy control mechanism, reliant upon the temperature, light and water content in the soil [13]. By decreasing the intensity of light, the plant residue on the surface of soil disturbs quality of light, by acting as a filter [14]. All wave lengths of light lies between 190 and 700nm (ultraviolet light and visible light) may be distracted by a single small dry leaf of plant residues, by this means varying light composition [8].

Plant residues covering the surface of soil filter light and decrease the ratio of far red and red light related to full sunlight, which decreases or even prevents weed plant germination that need full sunlight to germinate [12]. During the day, Plant residue on the surface of soil reduces the thermal amplitude of the topsoil layers, so that seeds of weed that are sensitive to temperature change would be affected in the germination procedure [13]. Working with twenty tons per hectare of sugarcane harvest residue, $6.2 \%$ and $13.2 \%$ decrease in soil temperature at the 10 and $5 \mathrm{~cm}$ depths was perceived, respectively [15].

\section{Recommendation}

Continuous use of organic farming increased the growth and yield of different crops. Grain yield of wheat and rice improved considerably with the use of chemical fertilizers in combination with different organic matters but compost shown the most superior in this respect. As organic matter in the topsoil layer is present, you need to aware by the use of pre-emergence herbicides in fields covered by plant residues in areas of conventional tillage. In zero tillage fields pre-emergence herbicides must have characteristics including vapor pressure, photodecomposition, solubility and adsorption familiar with this new cropping system.

Weed management in fields where plant residues are not burned or in zero tillage systems have to be prudently deliberate by farmers, because on the soil surface plant residues only are not adequate to control weed sin the crop field. In these systems chemical weed control methods should antedate the new weed flora, quality and quantity of plant residue, management of weed seed bank, degree of weed invasion and precise herbicide choice.

\section{References}

1. Anonymous (2016) Pakistan economic survey 2015-16. Ministry of finance, Government of Pakistan.
2. Zaka MA, Hussain N, Sarwar G, Malik MR, Ahmad I, et al. (2004) Fertility status of Sargodha district soils. Pakistan Journal of Scientific Research 56(1-2): 69-75.

3. Espeby L (1989) Germination of weed seeds and competition in stands of weeds and barley. Influences of mineral nutrients. Department of Crop Production Science, Swedish University of Agricultural Sciences.

4. Adkins SW, Simpson GM, Naylor JM (1984) The physiological basis of seed dormancy in Avenafatua III. Action of nitrogenous compounds. Physiologia plantarum 60(2): 227-233.

5. Sobrero MT, Ochoa MDC, Chaila S (2004) Potencial Alelopatico de Wedelia glauca: Efecto sobre species horticolas. Planta Daninha 22(1): 71-75.

6. Santos JCF, Souza ID, Mendes ANG, Morais AD, Conceicao HD, et al. (2002) Efeito de extratos de cascas de cafe e de arroz na emergencia e no crescimento do caruru-de-mancha. Pesq Agrope Brasileira 37(6): 783-790.

7. Trezzi MM, Vidal RA (2004) Potencial de utilizacao de cobertura vegetal de sorgo e milheto na supressao de plant as daninhas em condicao de campo: II-Efeitos da coberturamorta. Planta daninha. Londrina, PR China, 22(1): 1-10.

8. Velini ED, Trindade MLB, Cavenaghi AL, Negrisoli E (2003) Influencia da palhanaocorre ncia de plantasdaninhas e naeficiencia de herbicidas. In: Fancelli AL, Dourado NE, Piracicaba D (Eds.), estrate gias demanej oparaalta produtividade ESALQ/USP/LPV, Milho, pp. 198-208.

9. Theisen G, Vidal RA (1999) Efeito da cobertura do solo com residuos de aveia preta nas etapas do ciclo de vida do capimmarmelada. PlantaDaninha. Londrina 17(2): 189-196.

10. Vidal RA, Theisen G (1999) Efeito da cobertura do solo sobre a mortalidade de sementes de capim-marmeladaemduasprofundidades no solo. Plantadaninha 17(3): 339-344.

11. Pitelli RA, Durigan JC, Rossello R (2001) Ecologia das plantasdaninhas no sistema de plantiodireto. ROSSELLO, RD Siembradirecta en el cono sur. Montevideo: PROCISUR 203-210.

12. Christoffoleti PJ, De Carvalho SJP, Lopez-Ovejero RF, Nicolai M, Hidalgo E, et al. (2007) Conservation of natural resources in Brazilian agriculture: implications on weed biology and management. Crop Protection 26(3): 383-389.

13. Velini ED, Negrisoli E (2000) Controle de Plant as Daninhasemcanacrua. In: Congresso Brasileiro da Ciencia das Plantas Daninhas. Foz do Iguac-u. Anais. Foz do Iguac-u: Sociedade Brasileira da Ciencia das Plantas Daninhas pp. 148-164.

14. Kogan M, Apablaza P (1999) Control de malezas en el cultivo del tomate (Lycopersiconesculentum Mill). Ciencia e Investigacion Agraria 26(2): 119-124.

15. Azania AAPM, Azania CAM, Gravena R, Pavani MCMD, Pitelli RA (2002) Interferencia da palha de cana-de-acucar (Saccharum spp.) naemergencia de especies de plantasdaninhas da familia Convolvulaceae. Plantadaninha 207-212. 
Your next submission with Juniper Publishers will reach you the below assets

- Quality Editorial service

- Swift Peer Review

- Reprints availability

- E-prints Service

- Manuscript Podcast for convenient understanding

- Global attainment for your research

- Manuscript accessibility in different formats

( Pdf, E-pub, Full Text, Audio)

- Unceasing customer service

Track the below URL for one-step submission https://juniperpublishers.com/online-submission.php 